University of New Orleans

ScholarWorks@UNO

Spring 1991

\title{
The Power behind the Pronoun: Narrative Games in Calvino's If on a Winter's Night, a Traveler
}

Inge Fink

University of New Orleans, ifink@uno.edu

Follow this and additional works at: https://scholarworks.uno.edu/engl_facpubs

Part of the Italian Literature Commons

\section{Recommended Citation}

Fink, Inge. "The Power behind the Pronoun: Narrative Games in Calvino's If on a Winter's Night, a Traveler." Twentieth Century Literature: A Scholarly and Critical Journal 37.1 (1991): 93-104.

This Article is brought to you for free and open access by the Department of English and Foreign Languages at ScholarWorks@UNO. It has been accepted for inclusion in English Faculty Publications by an authorized administrator of ScholarWorks@UNO. For more information, please contact scholarworks@uno.edu. 


\section{Twentieth-}

\section{Century}

\section{Literature}

UI

The Power behind the Pronoun: Narrative Games in Calvino's If on a Winter's Night a Traveler

Author(s): Inge Fink

Source: Twentieth Century Literature, Vol. 37, No. 1 (Spring, 1991), pp. 93-104

Published by: Hofstra University

Stable URL: http://www.jstor.org/stable/441907

Accessed: 02/05/2011 16:07

Your use of the JSTOR archive indicates your acceptance of JSTOR's Terms and Conditions of Use, available at http://www.jstor.org/page/info/about/policies/terms.jsp. JSTOR's Terms and Conditions of Use provides, in part, that unless you have obtained prior permission, you may not download an entire issue of a journal or multiple copies of articles, and you may use content in the JSTOR archive only for your personal, non-commercial use.

Please contact the publisher regarding any further use of this work. Publisher contact information may be obtained at http://www.jstor.org/action/showPublisher?publisherCode=hofstra.

Each copy of any part of a JSTOR transmission must contain the same copyright notice that appears on the screen or printed page of such transmission.

JSTOR is a not-for-profit service that helps scholars, researchers, and students discover, use, and build upon a wide range of content in a trusted digital archive. We use information technology and tools to increase productivity and facilitate new forms of scholarship. For more information about JSTOR, please contact support@jstor.org. 


\title{
The Power behind the Pronoun: Narrative Games in Calvino's If on a winter's night a traveler
}

\author{
INGE FINK
}

Looking at the abundance of critical literature on Italo Calvino's If on a winter's night a traveler (Iwn) and marveling at the differences between some of the interpretations critics propose, one cannot help wondering what it is about the book that sparks such a variety of reactions. Is it just the usual proliferation of critical commentary that arises once a book has been found worthy of the New York Times Book Review? Although one cannot deny Calvino a certain amount of postmodernist trendiness-after all, we are looking at a novel that investigates the (erotic) properties of reading and writing and gives disciplines of literary theory their money's worth in cunning references to major ideas from Plato to Derrida-Iwn is more than just a collection of smart narrative gimmicks. There is a fundamental unreliability at the heart of the text, which seems to say "yes" to every critic's question and thus negates them all. This refusal to take sides suggests that we are dealing here with a playful text, a narrative carnival designed to mock the existing order, ringing with what Mikhail Bakhtin describes as the "laughter of carnival" that "asserts and denies . . buries and revives" (12).

Granted, the idea of literary play and literature as play is hardly new and has had its heyday in the 1960s and 1970s with the so-called postmodernist writers in America and their European colleagues, such as Calvino and Raymond Queneau, the founder of Ouvroir de Littérature Potentielle (Workshop for Potential Literature). However, the ludic strategies Calvino employs in Iwn defy the initial impression of 
art-for-art's sake playfulness; although he seems to share the postmodernist notions of the self-conscious text, the death of the author, and the absence of any univocal textual message, Calvino in fact undercuts contemporary theories and reestablishes the traditional hierarchies of literary discourse. Take the role of the reader, for example. Calvino's technique of opening and closing the book with a reference to itself being read leads us to believe that it is the reader, the central you, who makes the story possible and determines its beginning and end, and many critics have applauded this gesture of readerfriendliness, celebrating the novel as an incarnation of the teachings of reader-response criticism. However, as we probe beneath the surface, we find that this is the gambit of an intricate game, a game that cannot be played without the reader but is set up to trick him/her into realizing "that it is always [he], Calvino, who is in total control of the situation" (Du Plessix Gray 23).

The ludic impetus in the book rests on the simultaneous presence of two forms of literary discourse: on the one hand, there is the traditional novel, in which the reader identifies with more or less realistic characters whom the author, concealed by the "narrative voice," presents to him/her in an apparently objective manner. On the other hand, however, there is the postmodernist self-conscious novel in which the author strives to lay bare the mechanics of literary production, and the reader is constantly reminded of the text's artificiality. Calvino cleverly shifts between these two poles: he never lets his readers forget that they are reading a novel, but he cannot let go of their emotional attention, which is possible through identification only. Metacommentary in Iwn is thus carefully balanced by the promise of a strong story line to neutralize the reader's alienation and secure his/her interest.

As a close reading of the first chapter of the book will show, there are basically two game strategies at work in the text, complementing and supporting each other. The first is based on the identity between the reader outside the text and the one inside. By using the second-person pronoun, the author wins the readers' trust and draws them into the discourse, only to defer and finally deny narrative satisfaction by bringing the story to a premature close. The second strategy comes into play when the reader is dissociated from the Reader, who begins his life as the protagonist of a novelistic narrative. The "real" reader watches how the author plays with his characters, establishing his power by assigning names and pronouns. Although it might seem as if we are watching the game from a safe place outside the discourse, we are nevertheless the ones for whom it is intended: 
through identification with the characters and our (erotic) desire to discover the mystery we deliver ourselves into the hands of the author, who wins the game by drawing us into the narrative almost against our will.

The book starts with "Italo Calvino, who hadn't published for several years" (Iwn 4), informally chatting with the reader about the purchase of the book and his/her intentions to read it. Because the author introduces himself with the name on the book cover, we never doubt that the voice speaking to us through the text is that of the "real" Calvino, talking to us, the "real" readers. This impression is supported by the apparent authenticity of the assumptions he makes-the universally familiar details about the bookstore, the general preparations made for reading. The reader, assured that he/she is "the sort of person who, on principle, no longer expects anything of anything" (4), feels secure in this position of skeptical superiority and accepts the idiosyncrasies of the text as the product of "the unmistakable tone of the author" (9). The result is that the reader cannot but trust the voice that so effortlessly cuts across the border between the world inside the text and the one outside. What he/she does not know, however, is that the author, although he calls himself Italo Calvino, is but the first character in the book, soon to be joined by others. And the person he is talking to, the pronoun "you" that the reader identifies with, is in fact his first creation. So before we as readers plunge into what we take as the story proper, the incipit headed "If on a winter's night a traveler," we are already caught up in a complicated system of pronouns and relationships: There is the (implied) author, the "I" parading as the real Italo Calvino, talking to an imaginary "you," whom the reader takes to be himself/herself. The game is thus set up, with the "I" at an early advantage: he is already playing, whereas the reader, who still expects a traditional novel, is being played with.

Once the reader, who after this unexpected "preface" is more eager than ever to read the story, has started the promising narrative, he/she encounters another obstacle that prohibits straightforward reading pleasure-the metacommentary:

The novel begins in a railway station, a locomotive huffs, steam from a piston covers the opening of the chapter, a cloud of smoke hides part of the first paragraph. ... The pages of the book are clouded like the windows of an old train, the cloud of smoke rests on the sentences.

This is certainly not the kind of opening to be expected from a straightforward novel. But before we have time to wonder, "the man" 
(10) appears, and with him the promise that there will be some action before long. The enigmas proposed by this unknown figure prove stronger than the initial puzzlement at the metacommentary. "I am the man who comes and goes between the bar and the telephone booth," the stranger introduces himself. "Or rather: that man is called 'I' and you know nothing else about him" (11). Another enigma: who calls him "I," who makes him move about the railroad station? Because of our impatience to find out about the "I" and the story, we are likely to ignore the warning we are offered:

Watch out: it is surely a method of involving you gradually, capturing you in the story before you realize it-a trap. Or perhaps the author still has not made up his mind, just as you, reader, for that matter, are not sure what you would most like to read. . . .

So it is again the author at work behind the scenes, "[piling] supposition on supposition in long paragraphs without dialogues, a thick, opaque layer of lead" (14), thereby obscuring the plot instead of developing it. The array of dramatis personae is getting increasingly complicated: whereas on the opening pages we had the "I" of the author talking to some insufficiently defined "you," we have now the "I" of the character-narrator, talking about "him," the author, to (presumably the same) "you"; a jungle of pronouns almost too thick to penetrate. And just before we begin to lose our patience, the story unfolds: we learn some facts about the I-narrator and follow him into the railroad café, but as we are about to become engrossed in the narrative, another metacommentary disturbs our pleasure by telling us about the "fragments of conversation that seem to have no function beyond that of depicting the daily life of a provincial city" (17) and alerting us to the "murmuring effect" (18) the story strives to capture. The technique is the same as described above: the narrative voice keeps destroying the illusion of realism, but just before we distrust it enough to dissociate ourselves and/or stop reading, the next clue to solve the mystery of the story appears on the narrative horizon and the intrigue intensifies.

Since, as Calvino himself tells us, a novelistic discourse cannot develop without a (female) Third Person (Iwn 141), the introduction of Madame Marne is a crucial moment in the traveler's story. The enigma surrounding her is so strong that it is possible for the author to combine narrative and metacommentary in the same sentence without losing our interest:

I have-no, the author has-been circling around the feminine presence ... and it is your expectation, reader, that drives the 
author toward her; and I, too, though I have other things to think about, there I let myself go, I speak to her. . . .

If we were not too impatient to find out about the woman and her role in the mystery, we would notice the subtle statement on the dynamics of fiction in this passage: the relationship between author, character, and reader. The narrative $I$, formerly in accordance with the third-person author, dissociates himself from both reader and author when he agrees to speak to the woman in the interest of the story (and thus in our interest) although he has other things to do. At the same time, however, he acknowledges that he is a figure in the discourse the author has built up around the "feminine presence." The narrator thus intensifies the illusion that he is a real person capable of decisions-a vital factor in a realistic narrative - at the same moment he declares himself a character in the story. And like the character/narrator, we, the readers, find ourselves getting involved against our will.

The game strategy emerges clearly from these few passages: by creating suspense the author captures our interest, but he keeps deferring the consummation of our curiosity by means of metacommentary, the complicated proliferation of pronouns, and eventually by arresting the story altogether. According to Elizabeth Bruss, the basic factor in any game is parity between the players because "a game, by definition, is the encounter between equally matched and equally creative participants" (154). Parity, however, can only be achieved if the partners are playing at an even risk; a game would not be fair if one had more to lose than the other. In Calvino's game we, the readers, risk frustration: letting ourselves be dragged into the story, we are bound to suffer from aroused and dissatisfied curiosity. The author, on the other hand, risks oblivion: if our frustration exceeds a certain limit, we will probably put down the book and never pick it up again. Since he cannot know where this boundary lies with each individual reader, the author can only speculate as to how far he can go in his deviation from a traditional narrative. Like a careful gambler he has to establish a balance between risk and security: he intersperses the experimental metadiscourse with appetizing chunks of a good story line to secure our interest.

However cunning, this oscillation between story and commentary is not the end of the game: at the point where the author might expect us to call his hand on keeping us in limbo between identification and estrangement (or when we might simply become bored with this constant switching back and forth between discourses), he shifts gears, and the sudden ending of the story about the traveler in the nocturnal 
railroad station signals the advent of a new game: "just when you are beginning to grow truly interested, at this very point the author feels called upon to display one of those virtuoso tricks so customary in modern writing, repeating a paragraph word for word" (25). For us there is of course no such repetition; our text goes on and we are forced to conclude that the "you" we have taken as a reference to ourselves is apparently directed at somebody else now. Just as the narrative voice in the first incipit is split up in "he" (author) and "I" (narrator), the reader ceases to be an unproblematic entity: the text turns into a story when the experience of the "Reader who is reading" becomes different (at least partially) from that of the "Reader who is read" (Iwn 141), a change that is confirmed at the moment when Ludmilla enters the narrative stage and occasions the capital $R$ in the protagonist's name, the sign that marks him as a character.

As a result, the former identity of reader and Reader is replaced by identification: as the novelistic plot develops, the reader moves to the sidelines of the discourse and assumes the position of an observer, but he/she is nevertheless bound to the Reader by the magic of the second-person pronoun. In the game that is about to unfold the reader ceases to be the primary goal of the author's playful manipulation: he/she can watch how the Reader is being tossed back and forth between two identities, that of an independent character and that of a mere plaything, a pawn in the narrative game. But let us not rejoice too early: although we are given a frame narrative that we can follow to the end, we are not exempt from the author's game. Through identification with the protagonist we are still emotionally dependent on the one who determines his fate, and we are still readers of the incipits, bound to be disappointed every time they break off. Our desire to know the story's outcome keeps us securely within the author's circle of influence.

By introducing himself into the story as a mentor and critic, the author simultaneously creates and destroys the illusion of the Reader as an independent character who makes and assumes responsibility for his decisions. Very much like the I-narrator in the first incipit, whose conversation with the woman in the bar is necessary for the development of the story, the Reader is called upon to begin a relationship with Ludmilla. The author, seemingly dependent on the Reader's initiative, stands behind him like a benevolent father, suggesting various strategies of approach. "Don't waste time, then, you have a good excuse to strike up a conversation" (29), he tells him. "Go on, don't let the conversation die. Say something; just keep talking" (30). The Reader, apparently a good-natured but somewhat slow fellow, 
gives in to the author's coaching only to be reproached for passivity later on in the book:

But do you imagine it can go on in this way, this story? No, not that of the novel! Yours! How long are you going to let yourself be dragged passively by the plot? You had flung yourself into the action, filled with adventurous impulses: and then? Your function was quickly reduced to that of one who records situations decided by others, who submits to whims, finds himself involved in events that elude his control. Then what use is your role as protagonist to you? If you continue lending yourself to this game, it means that you, too, are an accomplice of the general mystification [in the world of books, authors, and counterfeiters].

Ironically, later in the novel when the Reader jumps into action and engages in a sexual encounter with Lotaria, Ludmilla's sister, the author disapproves of his "independence" and expresses contempt for this immoral act:

Reader, what are you doing? Aren't you going to resist? . . . You're the absolute protagonist of this book, very well; but do you believe that gives you the right to have carnal relations with all the female characters? . . . Wasn't your story with Ludmilla enough to give the plot the warmth and grace of a love story? ... It's natural for you to want to get even, after you have followed events of pages and pages with passive resignation, but does this seem the right way to you? (219)

There is, of course, no question of the Reader getting even with his maker; he is not only an accomplice of the "general mystification" of the text but its major product. The author pretending to be outraged at the Reader's actions obscures this fact, but in doing so he unmasks the nature of the narrative game: in performing the grand gesture of "I set thee free!" the author reiterates and reconfirms the relationship between subject ( $\mathrm{I}$, the liberator) and object (you, the liberated). There is no freedom for the Reader/character because he can only seemingly escape the grasp of the author, who makes up the rules of the game.

The author's omnipotent position in the discourse is even more obvious when he addresses the central "you" to Ludmilla, hitherto "the Third Person necessary for the novel to be a novel, for something to happen between that male Second Person and the female Third" (141). By shifting pronouns at his convenience, the author has the power to spotlight certain characters and thus make them come alive:

This book so far has been careful to leave open to the Reader who is reading the possibility of identifying himself with the 
Reader who is read: this is why he was not given a name, which would automatically have made him the equivalent of a Third Person, of a character (whereas to you, as Third Person, a name had to be given, Ludmilla), and so he has been kept a pronoun, in the abstract condition of pronouns, suitable for any attribute and any action. Let us see, Other Reader, if the book can succeed in drawing a true portrait of you, beginning with the frame and enclosing you from every side, establishing the outlines of your form. (141-42)

It is the command over the pronouns that cements the author's superiority: the "general male you, perhaps brother and double of a hypocrite I" (141) has changed places with the third person "she" and has temporarily vanished from the narrative horizon. Although he disappears into invisibility, the Reader is nevertheless at the author's disposal and can be called up again at any moment: "Reader, prick up your ears" (147).

Don't believe that the book is losing sight of you, Reader. The you that was shifted to the Other Reader can, at any sentence, be addressed to you again. You are always a possible you. Who would dare sentence you to loss of the you, a catastrophe as terrible as the loss of the I. For a second-person discourse to become a novel, at least two you's are required, distinct and concomitant, which stand out from the crowd of he's, she's, and they's.

So the narrative discourse, the locus of the author's game, decides the existential fate of the characters. Although their existence and interaction is vital for the story, it is the author who pulls the strings on his puppets. He explicitly dominates the love scene between the two Readers, their most private encounter as one would assume, by shifting the second-person pronoun from one to the other and then to both of them: "In short, what you are doing is very beautiful but grammatically it doesn't change a thing. At the moment when you most appear to be a united voi, a second person plural, you are two tu's, more separate and circumscribed than before" (154). As a result, the author's voyeuristic presence in the relationship of his characters elevates him to the position of a god, the ultimate divine I/eye of the discourse.

Although there is no indication in the text of the two lovers' knowing that their intimacy is spied upon by the master of the story, the protagonist gradually awakens to the fact that he is a fictional character. Because a sudden revelation of this kind would spoil the novelisticrealistic effect the frame narrative is trying to achieve, the author carefully builds up to the point of epiphany by meditating on the 
relationship between life and literature. "[How] to establish the exact moment in which a story begins?" he muses. "The lives of individuals of the human race form a constant plot" (153). Similarly, the Reader begins to question the distinction between the stories he is reading and the story he is living. When his brief sexual encounter with Lotaria is prematurely interrupted, he hopes that his fragmented love life will be rewarded by a complete narrative: "Now it is the stories you live that break off at the climactic moment: perhaps you will be allowed to follow the novels you read all the way to the end" (220). He does not finish the novels, unfortunately, but he discovers the rules of the game: he finds out that the titles of the fragmentary novels he has in vain tried to locate form the first sentence of a new story; his quest has come full circle and can theoretically be repeated infinitely. Confronted with the intricacy of the game, the Reader realizes that all he can do is surrender to its rules. When he is told that there are only two alternative endings for a novel- "the continuity of life [and] the inevitability of death" (259)-he chooses the former and marries Ludmilla. By allowing the Reader to end his own story by finishing the book, the author leaves us with a last impression of the protagonist's independence and closes on a note of characterological integrity.

As indicated above, the power the author displays in his game with the characters is not limited to the fictional level alone. The reader outside the text, although divided from his/her namesake in the story by the capital $R$, is never outside the ludic manipulations of the text. By identifying with the protagonist of the frame narrative and all the I-narrators in the various incipits, the reader is bound to be trapped in each story and thus at the mercy of the author who establishes the characters' identities and moves them about on the fictional stage. It is not that we were completely unaware of this, however: the author takes great pains to tell us time and again that we should not trust the voice speaking to us through the story. In fact, the more mimetic and lifelike a narrative seems, the more we have to watch out. In the incipit headed "Outside the town of Malbork," beguilingly credible in its realistic setting, we cannot determine the number of characters because it is the author who assigns them names and characteristics, and we have nothing but names and words to guide us in the vast kitchen of his imagination. So even if we know that the author is unreliable and not to be trusted, he is the only one who can satisfy our reading curiosity once we have taken the bait of a good exposition. As we have seen in the analysis of the first incipit, the readers' interest and cooperation are maintained through the creation of powerful textual enigmas that 
neutralize the effect of the metacommentary. The incipits, as Carl Malmgren observes, "[share] the main features of the detective-thriller: eros, mystery, suspense" (112). The combination of these three factors in Iwn proves too powerful for any reader to resist.

What is it, one might ask, that makes us such helpless victims of these textual properties and, by implication, of the author who controls them? And why does Calvino draw our attention to this irresistible attraction of a story, when, as he frankly tells us, there is nothing we can do to free ourselves from this influence?

Ever since Roland Barthes established the connection between sexual and textual pleasure, various critics have investigated the essentially erotic nature of texts. In Iwn Calvino literalizes the postmodernist concept of a poetics of desire, and the relationship he proposes between reader, writer, and text bears all the characteristics of an erotic encounter. "What might strike the reader . . a as possibly a bit odd," Mary McCarthy writes in her review of the book, "is the insistence on the Reader's anticipation; as though this were an ars amoris and the whole first chapter... were the foreplay, stimulation of erectile tissue prior to the act of reading as recommended by a rather permissive sex manual" (3):

This should be a hint of what is to follow: consummation withheld - a series of beginnings, ten to be exact, ten novels that break off just as they are getting interesting, ten cunningly regulated instances of coitus interruptus in the art and practice of fiction.

Following McCarthy's candid analogy, Malmgren explores the dynamics of eroticity and how they act as the driving force in a literary text. The pleasure of reading, for him, is based on the desire for difference: "Opening a fictional text, a reader encounters Otherness, Difference; in fact, the Desire for exposure to Otherness, Difference, is essentially erotic in nature" (Malmgren 112). Our curiosity then is aroused by the presence of the Other (the text, the unknown, the enigma), and our cognitive activities are bent on discovering (conquering) the Heart of Darkness as it were.

The game we encounter in Iwn is thus fueled by the reader's erotic desire to unveil the mystery of the text, a desire the author only partially satisfies. His refusal to grant complete satisfaction is the basis of his superiority, which turns the act of reading into an (erotic) "power struggle in which the reader is at the mercy of the text" (Malmgren 113). In an interview conducted by Francine du Plessix Gray, Calvino confirms this observation, arguing that in the relationship between 
reader and writer the dissatisfaction of the former heightens the pleasure of the latter:

And of course there is always something sadistic in the relationship between writer and reader. In $[I w n]$ I may be a more sadistic lover than ever. I constantly play cat and mouse with the reader, letting the reader briefly enjoy the illusion that he's free for a little while, that he's in control. And then I quickly take the rug out from under him; he realizes with a shock that he's not in control, that it is always I, Calvino, who is in total control of the situation.

This tells us then that by abandoning ourselves to his text we deliver ourselves into the hands of a narrative macho man, and even if he chooses to disguise himself at times we should not be surprised at what we see when he decides to rip open the jester's motley cloak. Are we pleased with what we glimpse beneath the shiny folds? Why yes, say some critics: by making us aware that the joy of our reading is based on a certain mode of discourse, by showing us that our desire for the text is always directed at blissful relief in the ending of a story, no matter how open, Calvino proves that the traditional novel is alive and well and will eventually survive the deconstructivist onslaught. No, say others like Teresa de Lauretis, who in her analysis of the female characters in the book accuses Calvino of perpetuating the patriarchal notion that access to the symbolic order and written discourse as its primary mode of expression is a masculine prerogative. Writing, as Calvino presents it, "is the masculine activity par excellence" (De Lauretis 80 ), and he makes it very clear in his treatment of Ludmilla and Lotaria that women have no place in the world of letters as anything other than primarily passive recipients for the authorial word.

Looking at the discursive games Calvino plays with his $\mathrm{R} /$ reader, one is tempted to agree with De Lauretis. However, before we write him off as the ultimate male chauvinist, we must not forget that we are dealing with a playful author, a story-telling jester who has fooled us time and again throughout the book, and chances are that his stance as the Rambo of the narrative discourse is just another role he chooses to play, his last disguise. Calvino does not offer us easy answers on how to read and write; instead, he playfully exposes the dichotomy that lies at the core of the postmodernist controversy: Do we want to continue to engage in the pleasure of reading as we know it, trusting the crafty author/lover with our textual satisfaction? Or do we opt for the bold journey to where no one has gone before, leaving behind the securities as well as the confinements of tradition? If on a winter's night a traveler 
steers clear of any dogmatic predictions as to the future of the novel, but through his ludic manipulations Calvino shows us that we cannot resist the temptation to read, and that it is essentially our desire for the text and its pleasures that will insure the existence of narrative discourse.

\section{WORKS CITED}

Bakhtin, Mikhail. Rabelais and His World. Trans. Helene Iswolsky. Cambridge, MA: MIT Press, 1986.

$\rightarrow$ Bruss, Elizabeth W. "The Game of Literature and Some Literary Games." New Literary History 9 (1977): 153-72.

Calvino, Italo. If on a winter's night a traveler. Trans. William Weaver. San Diego: Harcourt, 1981.

De Lauretis, Teresa. "Calvino and the Amazons: Reading the (Post) Modern Text." Technologies on Gender: Essays on Theory, Film and Fiction. Bloomington: Indiana UP, 1987. 70-83.

Du Plessix Gray, Francine. "Visiting Italo Calvino." New York Times Book Review 21 June 1981: $1+$.

McCarthy, Mary. "Acts of Love." Rev. of If on a winter's night a traveler, by Italo Calvino. New York Review of Books 21 June 1981: 3-6.

Malmgren, Carl. "Romancing the Reader: Calvino's If on a winter's night a traveler." Review of Contemporary Fiction 6 (1986): 106-16. 